\title{
Communication
}

\author{
[Comunicação]
}

\section{Serum total and bone alkaline phosphatase and tartrate-resistant acid phosphatase activities for the assessment of bone fracture healing in dogs}

\author{
[Fosfatase alcalina total, isoenzima óssea da fosfatase alcalina e fosfatase ácida resistente \\ ao tartarato na monitorização da cicatrização de fraturas ósseas]

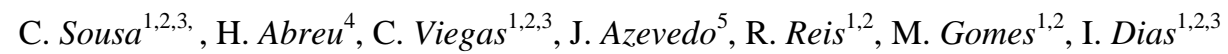 \\ 13B's Research Group - Biomaterials, Biodegradables and Biomimetics, Department of Polymer Engineering, \\ University of Minho, AvePark, 4806-909 Taipas, Guimarães, Portugal \\ ${ }^{2}$ Life and Health Sciences Research Institute - ICVS/3B's, PT Government Associate Laboratory, \\ Braga/Guimarães, Portugal \\ ${ }^{3}$ Department of Veterinary Sciences, School of Agrarian and Veterinary Sciences, University of Trás-os-Montes e \\ Alto Douro, Quinta dos Prados, P.O. Box 1013, 5001-801 Vila Real, Portugal \\ ${ }^{4}$ Veterinary Teaching Hospital of University of Trás-os-Montes e Alto Douro, Quinta dos Prados, \\ P.O. Box 1013 - 5001-801 - Vila Real, Portugal \\ ${ }^{5}$ CECAV - Centre for Studies in Animal and Veterinary Sciences; Department of Animal Sciences, School of \\ Agrarian and Veterinary Sciences, University of Trás-os-Montes e Alto Douro, Quinta dos Prados, \\ P.O. Box 1013 - 5001-801 Vila Real, Portugal
}

Bone modeling and remodeling are the result of the osteoblastic and osteoclastic cell activities (Allen, 2003). The biochemical markers of bone metabolism reflect the bone turnover process and are usually divided into formation and resorption markers. Bone formation markers are enzymes or proteins secreted by osteoblasts during the bone formation process, such as bone-specific isoform of alkaline phosphatase (BALP), serum osteocalcin (OC) and serum procollagen type I $\mathrm{C}$ - and N-terminal propeptides. Bone resorption markers are those resulting from the breakdown of type I collagen during the bone resorption process and specific enzymes expressed in boneresorbing osteoclasts, namely tartrate-resistant acid phosphatase (TRAP), serum carboxyterminal telopeptide of type I collagen and urinary collagen type I cross-linked C-and $\mathrm{N}$ - telopeptide (Cremers et al., 2008).

The measurement of serum markers of bone metabolism could assist in the evaluation of the cellular function in the bone fracture healing process, providing near real time information about the organic response to the lesion and to the selected treatment. These assays could also provide a simple, accessible and accurate method

Recebido em 4 de junho de 2011

Aceito em 13 de junho de 2011

E-mail: csousa@utad.pt of assessing disease progression during the bone fracture healing process (Allen, 2003; Breur et al., 2004).

The aim of this study was to assess the serum activities of total alkaline phosphatase (tALP), BALP and TRAP and serum minerals - calcium (Ca), phosphorous (P) and magnesium (Mg) during fracture healing process in the dog to verify if these biomarkers could provide complementary non-invasive data on the bone healing process.

For this study, were selected dogs which were admitted to the Veterinary Hospital with an isolated, closed, complete and simple diaphyseal fracture of a long bone. The animals were aged between 18 months and 8 years old, with normal renal and hepatic functions and without history of pre-existing or ongoing orthopaedic disease. From January 2009 until the present moment nine dogs were admitted within these conditions. On admission day all of them were subjected to a complete physical examination, haemogram, serum biochemistry, urinalysis, thoracic radiographs and abdominal ultrasound. The fractures were treated surgically by stable internal fixation and monitored in the pre- 
operative period and in the post-operative period on days 10,20,30,60 and 90 using physical and $\mathrm{X}$-ray examinations. At the same time points, blood samples were taken to evaluate tALP, BALP and TRAP serum activities and also serum mineral concentrations. Additionally, blood samples were also collected in a sample of nine healthy and skeletally mature dogs (range 2 to 6 years old) to constitute a control group. In these animals the same bone biomarkers were measured every ten days and the mean performed. All samples were collected into plain tubes containing a clot activator at the same hour in the morning, in order to minimize the possible effect of circadian rhythm. The specimens were processed within 30 minutes after the blood collection, centrifuged at $2000 \times \mathrm{xg}$ during 10 minutes and the resulting serum decanted into $2 \mathrm{~mL}$ polypropylene cryovials. Serum samples were frozen and stored at $-80^{\circ} \mathrm{C}$ until assayed. All samples were analyzed in duplicate and the mean value obtained was used for statistical analysis. Commercial reagent kits were used for the determinations of tALP (Alkaline Phosphatase $^{\circledR}$, ref. 7D55-20, Abbott) and TRAP (Roche ACP®, ref. 04375351190) serum activities and serum minerals concentrations (Calcium Abbott, ref. 7d61-20; Phosphorus Abbott, ref. 7d71-2) by spectrophotometry. BALP serum activity was measured with a reagent kit (MicroVue BAP EIA, Quidel Corporation) by ELISA.

Analysis of variance was performed to determine statistical differences between groups and over time. The mean value of each parameter was compared with others in the same group at different time points by $t$-Student test and also compared between the different groups in study for the same time point. The degree of correlation between the different biochemical parameters was assessed using a Fisher test. The P-values and r-values of correlations were considered significant at $\mathrm{P}<0.05$.

In this study the values obtained in the control group for tALP and BALP serum activities were within the reference range reported for dogs between 3 and 7 years old (tALP: 44.89 $\pm 21.9 \mathrm{U} / \mathrm{L}$; BALP: $14.62 \pm 5.44 \mathrm{U} / \mathrm{L}$ ), published in an earlier study (Allen et al., 1998). The serum activity TRAP was $2.19 \pm 0.56 \mathrm{U} / \mathrm{L}$, and this value, according to the author's knowledge, is the first report for this biochemical parameter in the healthy dog (Sousa et al., 2011).

In the operated group, seven dogs showed an evolution that led to bone union, but other two dogs presented radiographic signs of a non-union process at the day 60 , without evidence of progression in fracture healing, a persistent fracture gap and osteolysis. In this manner, these two dogs were subjected to a second surgical procedure at this time point to remove the initial implants that weren't contributing to fracture stabilization, debridement and realization of a new rigid internal fixation. The dogs were then divided in two groups, one composed by the animals which showed an evolution in bone union - fracture healing group, and the other one with the animals that progressed to a non-union process - non-union group.

The pattern of variation of the bone biochemical markers is shown in Figure 1.

It was observed that the serum activities of tALP and BALP presented statistically significant differences $(\mathrm{P}<0.05)$ between the non-union and the fracture healing groups, with higher values in the fracture healing group during the postoperative period regarding to the non-union group. This difference had also been observed for tALP in an earlier study by Komnenou et al. (2005). In the non-union group, serum tALP and BALP activities were lower when compared to the baseline reference value of the control group, with significant differences on post-operative days $20 \quad(\mathrm{P}<0.05)$ and $60 \quad(\mathrm{P}<0.0001)$. These results could represent a suppression of the osteogenic response, which could have led to the development of a non-union process at the fracture healing site (Herrmann et al., 2002). On the contrary, in the fracture healing group, the serum BALP activity was always higher than that of the baseline reference value of control group until post-operative day 90, when the enzyme activity returned to the reference interval for this parameter. 
Total alkaline phosphatase

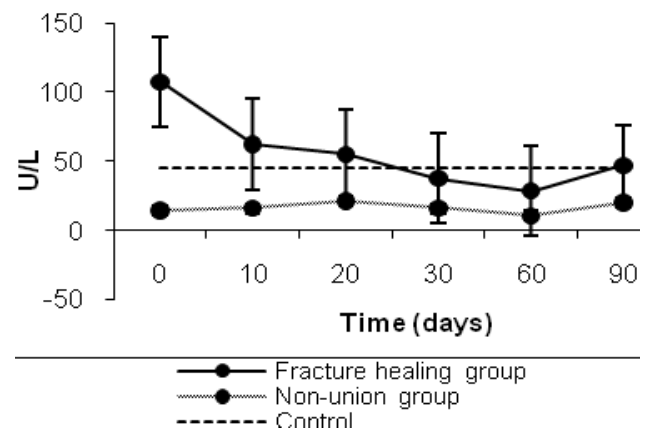

Tartarate-resistant acid phosphatase

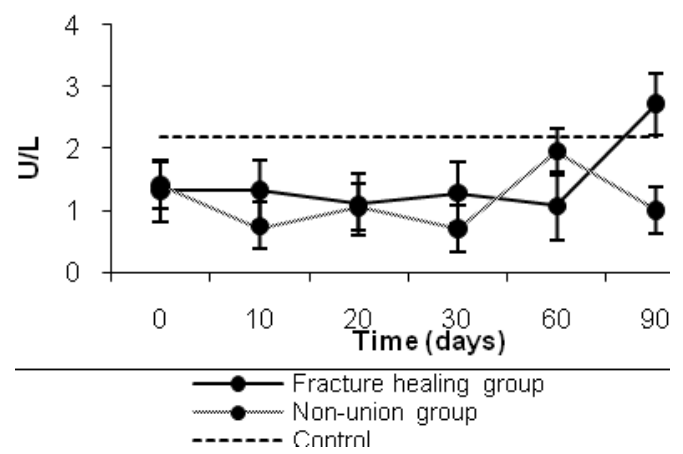

Phosphorus

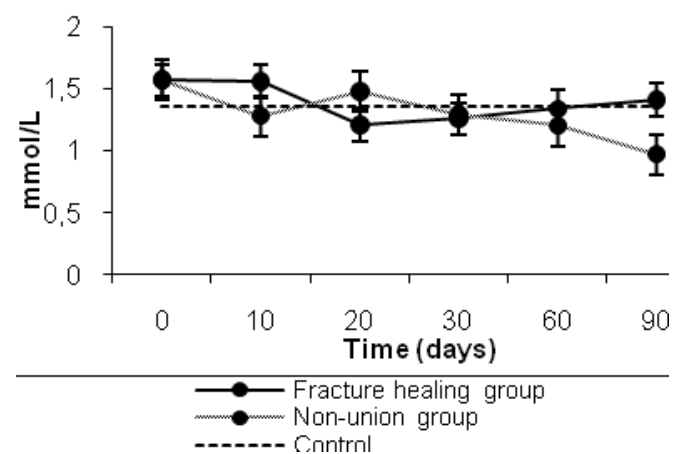

Bone alkaline phosphatase

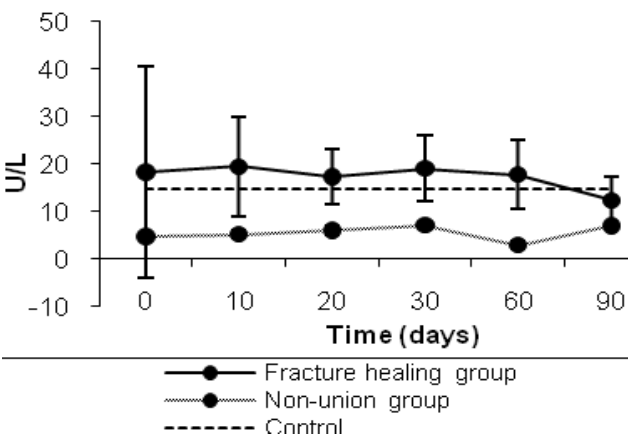

Calcium

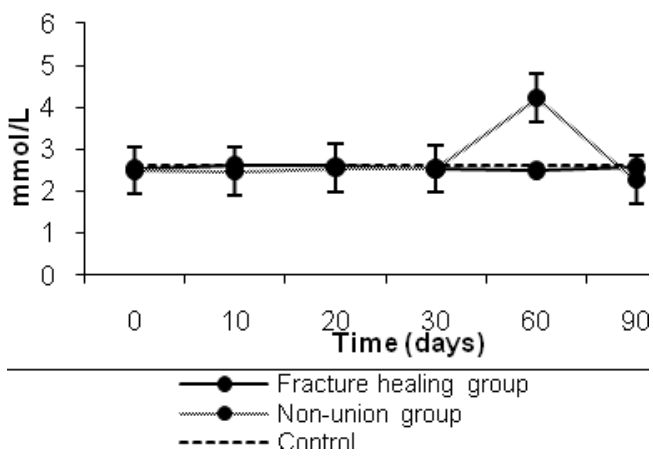

Magnesium

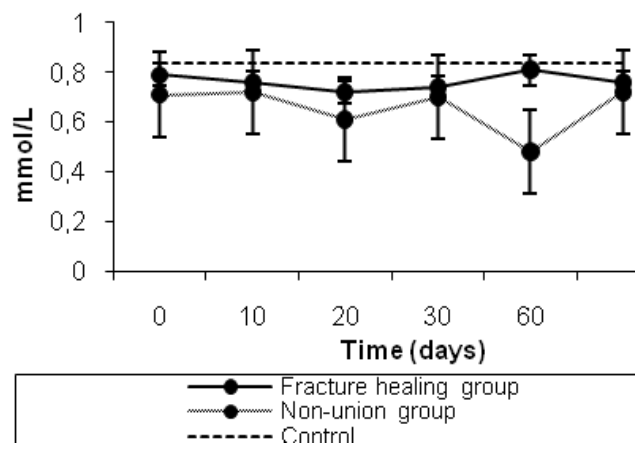

Figure 1. Mean \pm SD serum activities of tALP, BALP and TRAP, serum levels of Ca, $\mathrm{P}$ and Mg preoperatively on day 0 , and at different time intervals of the post-operative period on days 10, 20, 30, 60 and 90 in the fracture healing and non-union groups. 
Otherwise, serum TRAP activity showed a typical pattern of variation in the fracture healing group, with statistically significant low activity values during the post-operative period until day 60 , and a significant increase $(\mathrm{P}<0.05)$ after that. The low levels of TRAP could be explained by the prevalence of osteoblastic activity after surgical removal of necrotic tissue at fracture site and the posterior increases could correspond to the resorption of redundant mineralized callus tissue that occurs during the remodeling phase. This finding was also observed in the study of Seebeck et al. (2005) using an ovine model of bone fracture healing. So, further studies with a large sample of animals and with the intent of studying the cellular interactions and osteoclasts recruitment to the fracture healing site are needed to verify if serum activity TRAP could be suitable as a biomarker to indicate possible healing disturbances. The serum levels of $\mathrm{Ca}$ were significantly different between the two groups in study, but no significant differences could be observed for the serological variations of $\mathrm{P}$ between the fracture healing and non-union groups.

Finally, significant correlations were observed between tALP and BALP serum activities $(\mathrm{r}=0.8598 ; \mathrm{P}<0.0001)$ and $\mathrm{Ca}$ and $\mathrm{Mg}(\mathrm{r}=0.3410$; $\mathrm{P}<0.05)$ in the fracture healing group and between TRAP and $\mathrm{Ca} \quad(\mathrm{r}=0.7155 ; \mathrm{P}<0.01)$, TRAP and $\mathrm{Mg}(\mathrm{r}=-0.7123 ; \mathrm{P}<0.01)$ and $\mathrm{Ca}$ and $\mathrm{Mg}(\mathrm{r}=-0.8208 ; \mathrm{P}<0.01)$ in the non-union group. In the control group we also observed significant correlations between TRAP serum activity and $\mathrm{Mg}(\mathrm{r}=0.3970 ; \mathrm{P}<0.05), \mathrm{Ca}$ and $\mathrm{Mg}(\mathrm{r}=-0.7870$; $\mathrm{P}<0.01)$ and between TRAP and $\mathrm{Ca}(\mathrm{r}=-0.3431$; $\mathrm{P}<0.05$ ), which could evidence and reinforce the serum TRAP activity parameter as a bone resorption biomarker.

In conclusion, if the concentration of specific products from osteoblastic and osteoclastic activities could represent the bone callus development at the fracture site, then biomarkers of bone turnover would be indicators of the expected outcome (Kurdy, 2000). The determination of these biomarkers applied to the monitoring of the bone fracture healing process may become an accessible and complementary method to the X-ray examination. Bone biomarkers could allow an assessment of the dynamic process of bone fracture healing to provide a foundation for early decisions during the development of possible bone healing complications.

Keywords: dog, alkaline phosphatase, tartrateresistant acid phosphatase, fracture healing process

\section{RESUMO}

O objetivo deste trabalho foi estudar o padrão de variação da atividade sérica da fosfatase alcalina total (tALP), da isoenzima óssea da fosfatase alcalina (BALP) e da fosfatase ácida resistente ao tartarato (TRAP), assim como a variação da concentração dos minerais séricos durante o processo de cicatrização de fraturas ósseas no cão. A variação sérica destes marcadores do metabolismo ósseo foi avaliada em nove cães com fraturas diafisárias fechadas de ossos longos, submetidas a tratamento cirúrgico para osteosíntese. Durante o período pós-operatório, sete animais evoluíram no sentido de uma normal união óssea, sendo que dois deles desenvolveram um processo de não união óssea. Foram observados, relativamente à BALP, valores de actividade sérica mais elevados e com diferença estatística $(P<0,05)$ no grupo de animais que evoluiu no sentido de uma normal união óssea, comparativamente ao grupo de animais que evoluiu no sentido do processo de não união. No grupo de animais que evoluiu para a completa união óssea foram, adicionalmente, observados valores diminuidos $(P<0,05) d a$ atividade sérica da TRAP, até ao dia 60 do período pós-operatório seguido de uma elevação estatisticamente significativa após este período. Em conclusão, os biomarcadores do metabolismo ósseo poderão vir a constituir um método auxiliar de diagnóstico na monitorização do processo de cicatrização de fracturas ósseas, possibilitando, a detecção precoce de complicações pós-operatórias.

Palavras-chave: cão, fosfatase alcalina, fosfatase ácida resistente ao tartarato, fratura 


\section{REFERENCES}

ALLEN, M.J. Biochemical markers of bone metabolism in animals: Uses and limitations. Vet.Clin. Path., v.32, p.101-113, 2003.

ALLEN, M.J.; HOFFMANN W.; RICHARDSON D.; BREUR, J. Serum markers of bone metabolism in dogs. Am. J. Vet. Res., v.59, p.250-254, 1998.

BREUR， G.J.; ALLEN， M.J.; CARLSON， S.J.; RICHARDSON, D.C. Markers of bone metabolism in dog breeds of different size. Res. Vet. Sci., v.76, p.5355, 2004.

CREMERS, S.; GARNERO, P.; SEIBEL, M.J. Biochemical markers of bone metabolism. In: BILEZIKIAN, J.P.; RAISZ, L.G.; JOHN MARTIN, T. (Eds.). Principles of Bone Biology. 3.ed. San Diego: Academic Press, 2008. p.1857-1881.

HERRMANN, M.; KLITSCHER, D.; GEORG, T. et al. Different kinetics of bone markers in normal and delayed fracture healing of long bones. Clinical Chemistry, v.48, p.2263-2266, 2002.
KOMNENOU, A.; KARAYANNOPOULU, M.; POLIZOPOULOU, Z.S. et al. Correlation of serum alkaline phosphatase activity with the healing process of long bone fractures in dogs. Vet. Clin. Pathol., v.34, p.35-38, 2005.

KURDY, N.M.G. Serology of abnormal fracture healing: The role of PIIINP, PICP, and BsALP. J. Orthop. Trauma, v.14, p.48-53, 2000.

SEEBECK, P.; BAIL, H.J.; EXNER, C. et al. Do serological tissue markers represent callus formation during fracture healing? Bone, v.37, p.669-677, 2005.

SOUSA, C.P.; NERY, F.; AZEVEDO, J.T. et al. Tartrate-resistant acid fosfatase as a biomarker of bone turnover in dog. Arq. Bras. Med. Vet.,v.63, p.40-45, 2011 